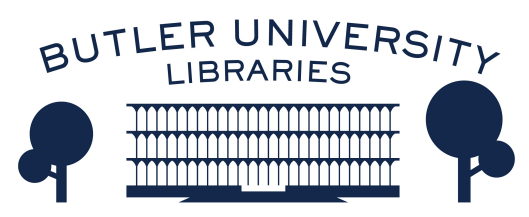

Journal of Hindu-Christian Studies

Volume 6

Article 6

January 1993

\title{
Ecology and Religion: Christian and Hindu Paradigms
}

Klaus Klostermaier

Follow this and additional works at: https://digitalcommons.butler.edu/jhcs

Part of the Religion Commons

\section{Recommended Citation}

Klostermaier, Klaus (1993) "Ecology and Religion: Christian and Hindu Paradigms," Journal of HinduChristian Studies: Vol. 6, Article 6.

Available at: https://doi.org/10.7825/2164-6279.1075

The Journal of Hindu-Christian Studies is a publication of the Society for Hindu-Christian Studies. The digital version is made available by Digital Commons @ Butler University. For questions about the Journal or the Society, please contact cbauman@butler.edu. For more information about Digital Commons @ Butler University, please contact digitalscholarship@butler.edu. 


\title{
Ecology and Religion:
}

\section{Christian and Hindu Paradigms}

\author{
Klaus Klostermaier
}

\author{
University of Manitoba
}

\begin{abstract}
NEITHER HINDUISM NOR Christianity had or have 'ecology' as their central focus. A contemporary Hindu or Christian ecology can be developed by rethinking and restructuring traditional teachings, amplifying seminal statements and linking these up with the dominating concern of the late 20th century, to 'save the earth'. In the context of a 'science and religion' seminar some years back one of my colleagues from the life sciences remarked: 'What we need today is an ecological messiah'. The task before us is that of the one preparing the way for such an ecological messiah, pulling together strands of Hindu and Christian traditional symbolism and doctrine conducive to a religious ecology. Both Hinduism and Christianity have to do a good deal of repenting and making good for neglecting and even violating nature. This is not the place to repeat what Arnold Toynbee or Lynn White Jr said about the 'religious roots of the ecological crisis' but we have to keep it in mind. We are treading on shifting grounds and even now we should not take it for granted that the majority of either leaders or followers of Christianity and Hinduism endorse a concern for nature as a religious cause. In the following I am exclusively concentrating on paradigms that have been or are supportive of a religious ecology, leaving out Advaitic unconcern for nature as well as Christian hostility towards 'corrupt nature' and other unhelpful positions.
\end{abstract}

\section{Eco-Religious Paradigms from the Hindu Traditions:}

\section{A. The Vedic Paradigm: The Earth as Dwelling Place for Gods and Humans}

The people who composed the Vedas must have known a great deal about the nature in which they lived and from whom they drew their sustenance. They worshipped a great many gods, who were initially considered by Western scholars 'personifications of natural phenomena,' such as Agni = Fire, Vaya = Wind, Indra $=$ Storm, Surya $=$ Sun, Usaa $=$ Dawn and so on. The devas were not so much personifications of natural phenomena, as we know today, but the medium through which Vedic people approached the powers of nature, which remained mysterious, both full of blessings and full of danger. The basic assumption underlying Vedic religion that led to the development of the elaborate sacrificial cult was the mutual dependence of men and gods (and ancestors). Vedic society was convinced that it needed the favours of the gods for survival and prosperity: but it was equally convinced that the devas needed the sacrificial offerings made by men for their 'power'. Vedic people imagined to live in a power-circuit, in which the crucial switch was constituted by the 'karma' of the sacrifice and the 'Brahman' formula of the Veda. There was a deep-rooted conviction that one had to pay a price for everything - that 
'nature' was not giving something for nothing; that humans had to return something to the 'powers' for the goods ('energies') which they received. It was apparently a fairly marginal existence which was possible under the given circumstances: survival was precarious and threatened by famine, disease, enemies and wild animals. Every catastrophe was necessarily attributed to a break in the power-circuit that connected the devas with the world of men: Vedic Indians did not assume that the gods were capricious (like those of the Greeks) but they considered them to be almost mechanically-acting elements in a power-circuit (deva - mantra dravya-vajamana) which was kept charged by the sacrifices performed by the competent members of the community (the Brahmins). If the power-circuit failed, the point where it had to be mended was the sacrificial karma.

\section{B. The Paradigm of the Smrtis: Hu- man Nature as Archetype}

Whereas ancient Vedic consciousness was shaped by the constant and inevitable intervention by humans in natural processes - an intervention which was fraught with danger and could only safely be mastered by application of the ritualistically fixed vajna - the developing societies of the Smrti period experienced interpersonal relationships as the most crucial contact with reality. The governing paradigm through which 'nature' was perceived was no longer the power circuit deva - mantra - dravya - yajamana operated through the vajna, but the vertical hierarchical order of society patterned on the archetype of the hierarchically created human nature.

The pivotal 'religious' activity was no longer the offering of sacrifices for immediate material benefits but the conforming to dharma - an all-comprehending 'law' with a social emphasis. Dharma has a variety of 'ecological' implications. The well known and often applied adage dharma raksato raksati expresses the conviction that 'loopreinforcement' depends on human's (conscious and 'moral') observation of a law by which everything is governed. The articulated dharma, as found in the law books, has further ecological dimensions insofar as it determines lawful ways of gaining a livelihood as against unlawful ones. The lawful occupations are those that conform to the general dharma - a dharma which protects the existence not only of humans but also of nature in the widest sense. Dharma itself has moral, social, political, as well as cosmic features.

Viewing dharma as the eternal, immutable law governing the universe, dharmasatra is essentially conservative: it endeavours to provide a foundation for a society which follows unchanging laws and thereby remains in permanent symbiotic harmony with its environment. Dharma would not be dharma if it did not ensure the mutual co-existence of all partners in the universe: it could not be the eternal law upon which man's own nature is founded if it led to a deterioration of living conditions. Indian tradition associates the visible deterioration of man's condition and of the quality of the environment to a truncating and mutilating of dharma: dharma which had been four-footed during the first age of mankind loses foot after foot - till it becomes almost totally crippled during the Kaliyuga. It is not the following of the law which brings about ecological (and other) calamities but the not following of it.

\section{The Puranic Paradigm: The Tem-} ple as Microcosmos

'Classical' Hinduism as codified in the $P u$ ranas was temple-centered. No village and no town was to be without its temple, and divine presence and protection were thought to depend on possessing images of God housed in temples. The temple itself was thought of as a microcosm. In numerous ancient Indian writings we read that the gods always play where groves are near, rivers and mountains and springs, and in towns with pleasure gardens'. Where such facilities 
did not exist naturally, they could be created by human ingenuity so as to attract the gods. The presence of water is essential above everything else: a temple could only be built near water. If no natural water-course or lake was available, an artificial pond had to be created. The pursusa-mandala according to which the plan had to be drawn up again gives a cosmic dimension to the building to be erected on a specific spot. Similarly the foundation-laying and the consecration rituals contained numerous cosmic implications: the actual structure had to be embedded in cosmic time and space.

The harmony of nature represented by the temple is not a purely external harmony as that created by the power-cycle of the Vedic vajna, nor a moral-social harmony created by a dharma centered in the human constitution, but a metaphysical one, realised in a yogic interiorisation of the whole universe, coming from the centre of being itself, into which meditation has brought the architect - the creator of the world in miniature.

There is an even higher dimension of 'ecology' in temple building: by creating abodes for the gods, fashioning (cultural!) environments one is satisfying the higher human needs - needs above the animal comforts of food and shelter. In many ancient texts we find the opinion expressed that a village or a town was not inhabitable until and unless a temple was built in its centre and worship was offered. We also find the injunction that only by following the highest and most aesthetic standards of architecture a temple could be expected to house the deity. No doubt we can appreciate the wisdom of this today. The total environment in which a truly human life can be lived must also contain dimensions of the 'transcendent'. An 'ecology' which leaves this out is less than complete, however well it may provide for adequate physical amenities and a good, working sewer system.

\section{A Vaisnava Paradigm: The Earth as the Body of God}

Central to the theology of Ramanuja, the great Sri Vaisnava acarya, is the so-called sariri-sarira bhova, the view that the relationship between deity and earth is that of soul and body. While resting on Vedic perceptions of the creation of the universe through the sacrifice of the primaeval purusa, it goes far beyond it in identifying the physical universe as the body of Visnu and distinctive geographical features with the divine reality. Philosophically it expresses the total dependence of the creature on its creator. Practically it could lead to a reverential attitude towards the whole creation. The world becomes God's temple and deserves to be honoured as one honours God's presence in the image. Since Vaisnavism is a living tradition even today, its paradigm could be used to develop a comprehensive religious ecology, without compromising either tradition or modern scientific notions.

\section{Eco-Religious Paradigms from Chris- tian Traditions:}

\section{The Sacramental Paradigm:}

Beginning with the New Testament, Christianity correlated physical and spiritual realities in the sacramental use of bread and wine for the Eucharist and of oil for supernatural healing. The New Testament emphasises the physical nature of the saviour's presence and attributes ultimate significance to his sacrificing a real human body for gaining the world's salvation. The early Church extended this sacramental paradigm by calling the Christian community 'Christ's Body' and paralleling the realities of the physical Church building and the body of Christ. A further extension of this notion took place in connection with the respect paid to the martyrs: the physical remnants of those who died in testimony to their faith were credited with quasi-sacramental powers. Miracles were attributed to their presence and the Church 
made it a regulation that a fragment of the bones of a saint had to be enshrined in every place of worship in order to make it 'holy'. The use of natural elements in rituals like baptism and the celebration of Easter water, fire, wind, rock - gave a sacramental dimension to all these natural materials in the context of worship.

\section{The Mytho-Mystical Paradigm:}

Christian worship, which originally must have been completely Jewish, assumed, under the impact of Graeco-Roman culture, features of mystery-religion. In its effort to make 'Christ the only Lord' Christians adopted rituals as well as language from Mithraism and other such cults in which a great deal of nature-mysticism and naturemythology was celebrated. The most prominent feature was the worship of the Sun which became the Christian worship of Christus Sol. It became the inspiration for Francis of Assisi's Canto del Sol.

The 'mythico-mystical' paradigm was not totally obliterated by the Reformation (which otherwise demythologised and demystified the Christian tradition): Johannes Kepler, a Lutheran, was guided by it to articulate his theory of the planetary system. Kepler was learned enough in classical literature to associate his guiding paradigm not only with the Trinitarian Godhead of Christianity but also with the Pythagorean-Platonic notion of the harmony of the spheres and helios-theos piety of neoplatonic sages. This mythico-mystical paradigm disappeared when a purely pragmatic and utilitarian type of science took over which not only dissolved the paradigm but a great deal of traditional life itself and which lead eventually to a split between the 'two cultures.'

\section{The 'Cultivation' Paradigm:}

Early mediaeval Benedictine monasteries in transalpine Europe became oases of advanced agriculture, horticulture and husbandry, and model institutions from which the larger communities learned. Benedictine agriculture was not only 'organic' but also 'holistic' and improved rather than destroyed the natural fertility of the soils and the aesthetic appeal of landscapes. With immense industriousness and great sensitivity the largely untamed forests and swamps of Central Europe were transformed into cultural environments which were - for the time quite ideal combinations of nature and civilisation. The emotional engagement of these monks with the nature surrounding them is evident also in the religious names given to many species of plants and animals and by aligning the 'Christian year of salvation' with the seasons of nature. The later parish priests would normally be working farms of their own; often they kept bees. There are many popular stories which show Christianity firmly integrated with the natural and cultural environment. The establishment of sacred buildings (churches, monasteries) would often reveal great environmental sensitivity.

\section{The 'Theosopic' Paradigm:}

Hildegard von Bingen is an early exponent of a Christian understanding of macrocosmmicrocosm correlations and of a visionary understanding of physical reality as a revelation of God's own being. The world revealed itself to her as the structured presence of God and from her knowledge of plants and organisms she gained an understanding of the nature of God that went far beyond the scriptural and traditional teaching. It was the kind of integration of physical and theological knowledge that found expression in Dun Scotus' De divisione naturae and Giordano Bruno's Della causa, principio et uno - both condemned by the Church authorities at the time! It was also the paradigm which Galileo Galilei used when giving equal importance to the 'book of nature' in coming to know God as the 'book of Scripture'. He too, was condemned. The Lutheran mystic cobbler Jacob Böhme, praised as the 'philosophus teutonicus' by contemporary scholars and poets met a similar fate with the publication of his 
Theosophia in Protestant Saxonia. One could continue the series through Paley's Physicotheology and Pierre Teilhard de Chardin's Phénomène Humain - and perhaps even Matthew Fox's Original Blessing, which did not find a better hearing among defenders of Christian orthodoxy, totally estranged from any real contact with or understanding of nature.

\section{Concluding Remarks:}

Hindu and Christian traditions have developed paradigms that have been and can be used in developing a viable religiously founded ecology. However, in the life and thought of most Hindus and Christians today there is little awareness of such paradigms and even less action along the lines suggested by them. With great regularity Christian authorities condemn and reject attempts to develop religiously relevant perceptions of nature that go beyond the folkloristic or metaphorical. Hindu authorities too have been far too busy with political and other matters to pay much attention to the development of a sound ecological theory from within the tradition.

That does not diminish the importance of the issue. Old traditions tend to show a great amount of inertia when it comes to recognising current needs or to undertaking appropriate action. I remember a Vatican Monsignor once telling me in reply to my question why a certain matter had not yet been taken up: 'Noi pensiamo in secoli' - we' think in centuries, not in decades or years. In all probability we will not have any more centuries if we do not act soon in matters of ecology. If we do not wish to surrender this serious issue to the quick-fixers, to those who want to patch up the wounds of the earth in order to continue exploiting her, we have to contribute from the wisdom of the great religious traditions, who have much thought and motivation to offer to those who really want to save the earth. 